\title{
American Mobilization and the Justice Cascade
}

In addition to civil society groups, and often tightly interwoven with them, state actors contributed to raising awareness of the mass violence in Darfur and contributed to its representation as human rights crimes. One interviewee from a large European country had worked for his foreign ministry's human rights division and represented his country on the ICC's Assembly of States during the period when the UN Security Council referred the Darfur situation to the court. A lawyer by training, he strongly stressed the primacy of human rights concerns ahead of other goals: "You need to give them justice, and once they have the feel that justice, more or less, is taken care of, then I think you can create within such a society a willingness to overcome postconflict and enter a new phase of peace building."

This chapter, on state actors and their linkages to civil society in the human rights field, highlights the case of the United States-among the countries considered here, the most pronounced supporter of a criminalizing response and a strong proponent of the application of the genocide label. After a brief review of the US Save Darfur campaign, a massive mobilization of civil society organizations, I look at American media representations (outliers in international comparison) and discuss government responses. Those responses show how a state-civil society amalgam emerged and made itself unmistakably heard with its intense pursuit of criminalizing definitions of the violence in Darfur. 
The American story is particularly interesting as the United States has never ratified the Rome Statute and generally keeps a critical distance from the ICC. William Schabas (2004) in fact writes about "United States hostility to the International Criminal Court" (see also Deitelhoff 2009). Specifically with regard to Darfur, the United States initially displayed considerable resistance against a referral of the Darfur situation to the ICC. Yet, in a surprising and quite radical turn, it eventually embraced a criminalizing strategy and abstained from the UNSC vote on Resolution I 593, thereby allowing the case of Darfur to be referred to the ICC. According to the Security Council minutes:

\begin{abstract}
ANNE WOODS PATTERSON (United States) said her country strongly supported bringing to justice those responsible for the crimes and atrocities that had occurred in Darfur and ending the climate of impunity there. Violators of international humanitarian law and human rights law must be held accountable. Justice must be served in Darfur. By adopting today's resolution, the international community had established an accountability mechanism for the perpetrators of crimes and atrocities in Darfur. The resolution would refer the situation in Darfur to the International Criminal Court (ICC) for investigation and prosecution. While the United States believed that a better mechanism would have been a hybrid tribunal in Africa, it was important that the international community spoke with one voice in order to help promote effective accountability. ${ }^{\mathrm{I}}$
\end{abstract}

I ask why the US government eventually aligned with a strong civil society movement, despite its refusal to ratify the Rome Statute. In the end, civil society, the federal government, and media alike were international outliers in their determination to articulate the story of Darfur as one of criminal-in fact, genocidal-violence. A closer look at representations that emerged from these American discourses sheds additional light on the nation-specific conditions that color representations of mass atrocities. They include the peculiarities of US civil society, the organization of government in the United States, and its media market. Based on interviews and media data, we shall also see, as we did in chapter 2, that the institutional logic of law still colors representations of mass violence at the periphery of the legal field, albeit in a weakened form compared to that applied at the center. Toward the end of this chapter, in a brief excursus, I examine how the US section of an international rights-based NGO, again Amnesty International, maneuvers within a highly mobilized civil society environment, dominated by Save Darfur, with which it disagreed on a number of positions. What organizational and linguistic strategies did it use to act effectively in this context? 


\section{THE SAVE DARFUR MOVEMENT IN THE UNITED STATES}

The United States Holocaust Memorial Museum took the lead in the American civil society movement when, in January 2004, it issued a genocide alert on the situation in Darfur. The first, widely publicized media pronouncements articulating the plight of the people of Darfur for a broad public soon followed. Eric Reeves, an English professor at Smith College and one of the leading individual problem entrepreneurs on Darfur, had his famous, trendsetting op-ed published in the Washington Post on February 24, 2004, following rejections of previous submissions. One month later, on March 24, the New York Times followed with an op-ed by Nicholas Kristof, the first in a series of his contributions on Darfur. A wave of other opinion pieces followed. Deborah Murphy (2007), in counting editorial responses to Darfur by select (prominent) US media in 2004, identifies twelve in April, eight in May, nine in June, sixteen in July, fifteen in August, and nineteen in September.

Following the USHMM's January 2004 genocide alert, the first op-ed pieces, and UN secretary-general Kofi Annan's April 2004 speech on the occasion of the tenth anniversary of the Rwandan genocide, a massive wave of civil society activism unfolded in the United States. It partly preceded, but also accompanied and followed, formal interventions by the UN and the ICC. Most noteworthy, the period between June 2004 and July 2005 witnessed the founding of the Save Darfur Coalition, which eventually brought together almost two hundred organizational members under its umbrella. Prominent among the great variety of groups were Christian evangelical groups, including Christian Solidarity International (CSI), that represented an important constituent bloc for then-president George W. Bush. These conservative groups and churches formed a rare coalition with liberal organizations such as the American Jewish World Service (AJWS); various specialized organizations, including the USHMM and Africa Action, a Washington, DC-based NGO; and mainstream human rights organizations such as Amnesty-USA.

Preceding and advancing the constitution of the Save Darfur coalition, the USHMM organized a July 2004 conference at the City University of New York. There Holocaust survivor and Nobel Peace Prize laureate Eli Wiesel delivered a forceful speech in which he linked the violence in Darfur to the Rwandan genocide. The wave of activism was further spurred by the release of the film Hotel Rwanda in September 2004, 


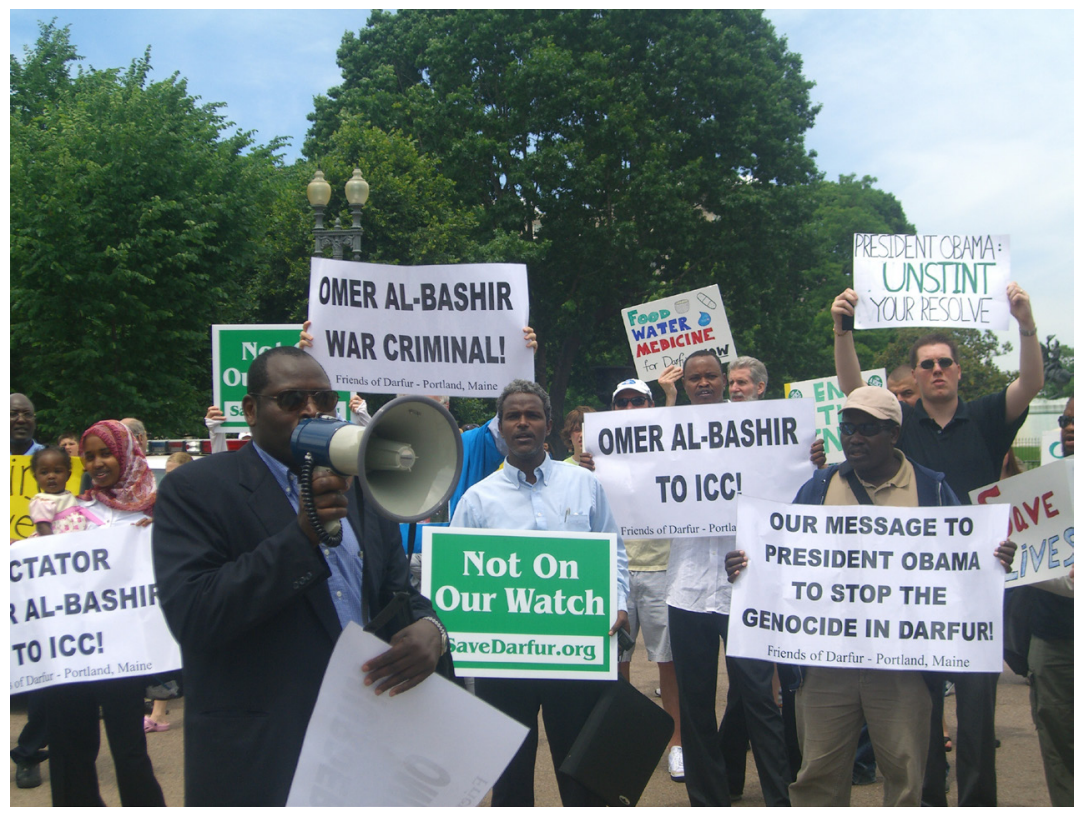

FIGURE 6. Save Darfur demonstration in Washington, DC.

which by depicting the Rwandan genocide in Hollywood fashion, helped explicate it for a broad public. About one year after the second peak of the violence in Darfur, in April 2005, Harvard's John F. Kennedy School of Public Policy hosted a largely student-led event on divestment from Sudan. One year later some fifty thousand people gathered on the National Mall in Washington, DC, for an impressive demonstration under the title "Save Darfur: Rally to Stop Genocide." Speakers included Barack Obama, Elie Wiesel, Nancy Pelosi, and celebrities such as George Clooney. Speakers and demonstrators demanded a UN peacekeeping force, better humanitarian access to refugees, adhesion to existing treaties and cease-fire agreements, and a commitment to a lasting peace agreement in the Abuja peace talks. Importantly, they also called for justice to be delivered (see figures 6 and 7). Along the way, activists sought to exert direct influence on the political process, as when Save Darfur leaders met with Deputy Secretary of State Robert Zoellick and organized a "National Call-in Day" on Darfur. And civil society organizations found strong resonance, and reinforcement, in the way American media covered Darfur. 


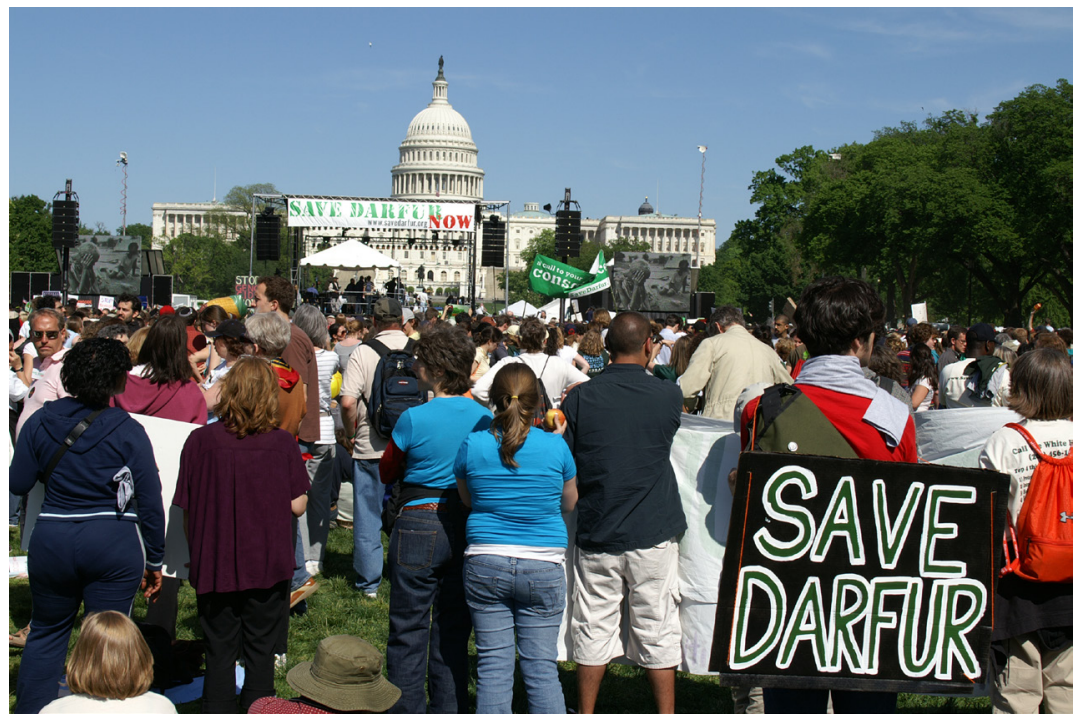

FIGURE 7. Save Darfur demonstration in Washington, DC.

\section{DARFUR IN US MEDIA}

The New York Times and the Wall Street Journal are among America's most prestigious print media; both are mainstream, though the former occupies the left-liberal and the latter the conservative end of the political spectrum. Neither the presidential administration nor Congress would be ignorant of positions taken by these papers. While a more detailed analysis of media is presented in chapters 8 and 9, I here highlight patterns that speak to the special role that US media played, in comparison to media elsewhere in the world, to generate a criminalizing account of the situation in Darfur. Numerous articles and commentaries appeared between 2003 and 2010 in both the New York Times and the Wall Street Journal. They acknowledged the suffering in Darfur, contributed to framing the violence, and built bridges to past mass atrocities (for details on analytic strategies see the introduction).

\section{Acknowledgment}

American media are more likely than those in the other seven countries in the comparison group to acknowledge most forms of victimization. 
This applies to all media documents, somewhat to news articles or reports, and decidedly to opinion pieces. ${ }^{2}$ Consider the reporting of killings (analyzed separately from natural deaths), of rapes, and of displacements in Darfur. Figure $8(\mathrm{~A}-\mathrm{C})$ shows that the likelihood that American media reports informed readers of killings and, especially, rapes was substantially higher than that for media reports from outside the United States. The same applies, even more strongly, to opinion pieces. Only for displacements do we find only minor differences, partially even a reversal of the pattern observed for the other types of victimization. This should not be surprising as addressing displacements is more in line with a humanitarian emergency and aid frame, as I show in detail in chapter 5.3

\section{Framing}

Framing, more than acknowledgment, is an interpretive endeavor. Where we find substantial variation in terms of acknowledgment of victimization and suffering, we might expect a wider range in the framing of violence. As in the interviews I conducted, the coding scheme for the analysis of media reports asked about different frames, the presence or absence of which in the articles were to be noted. Frames included rebellion or insurgency, humanitarian emergency, civil war, and criminal violence. Here I report only on the last-named frame as I am concerned with the criminalizing discourse on Darfur.

Figure 9.A shows that US media used the crime frame more often than those of other countries. Yet the difference is remarkable only for opinion pieces. There, where normative and value-based statements are expected, almost 60 percent of editorialists in all papers used the crime frame, whereas about three-quarters of opinion pieces in American media did so. The difference becomes more pronounced for the use of the genocide frame (figure 9.B). While US news reports cited the genocide frame more frequently, the difference more than doubled for opinion pieces. ${ }^{4}$

\section{Bridging}

In addition to frame selection, another way of making sense of news events that we otherwise cannot yet interpret is the strategy of bridging. Journalists cite past occurrences on which interpretive clarity has been reached and use them to shed light on current-day events. In the context 


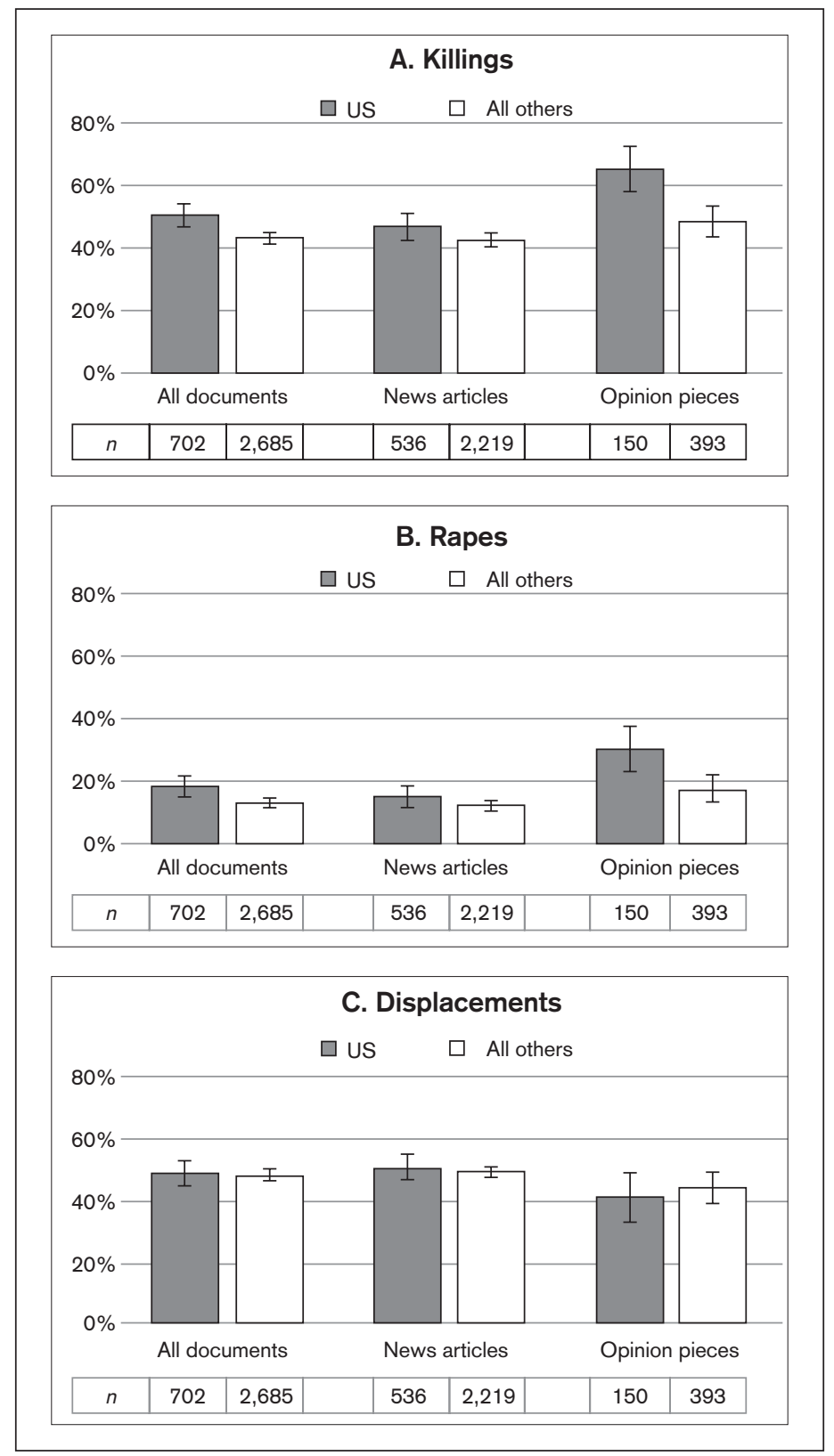

FIGURE 8. Percentage of US media documents that address killings, rapes, and displacements, compared to all other media documents. 
90 Justice versus Impunity
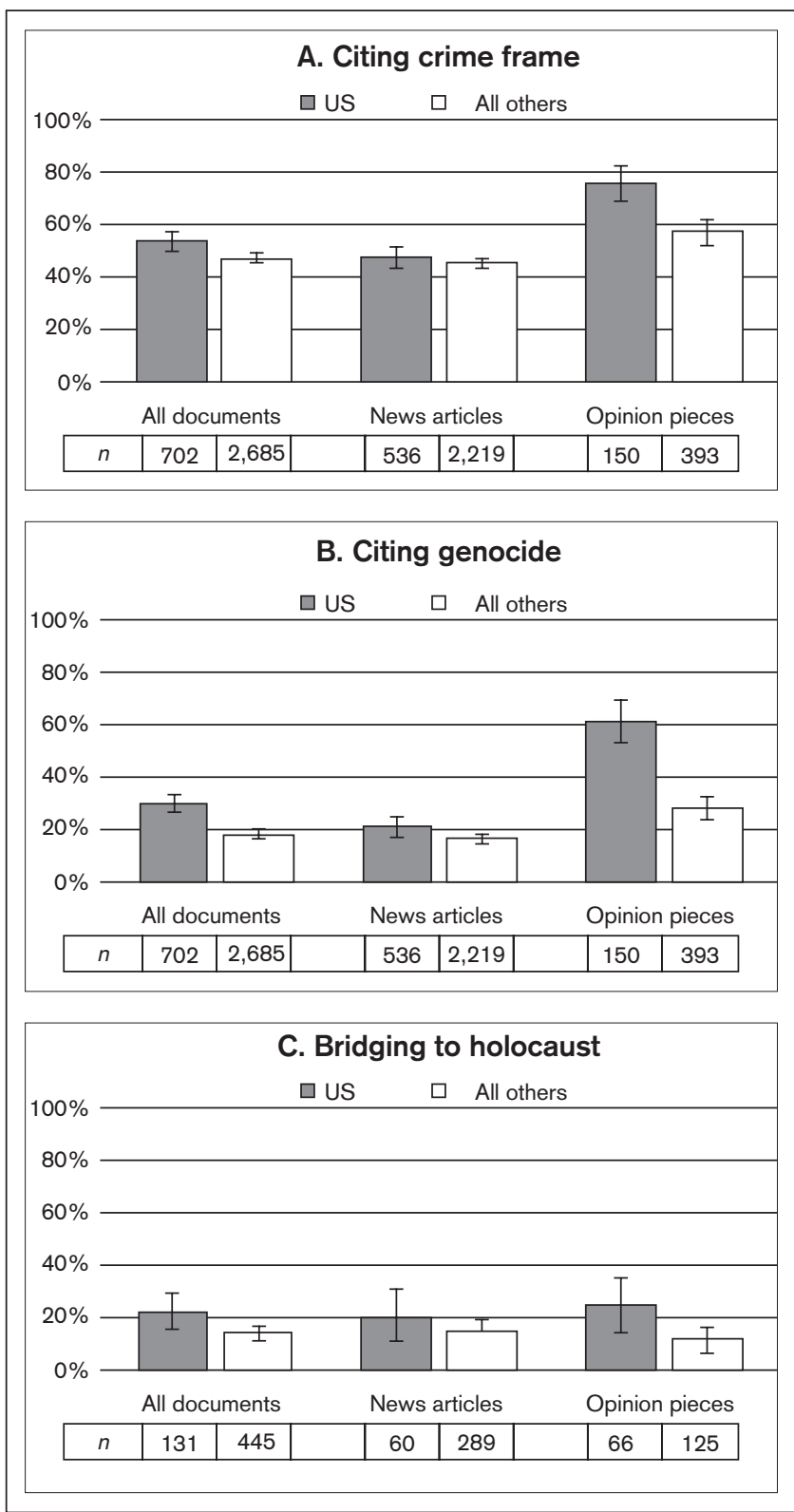

FIGURE 9. Percentage of US media documents citing the crime frame, using the genocide label, and bridging to the Holocaust, compared to all other media documents. 
of genocide, the most powerful reference is to the Holocaust. Figure 9.C shows the percentage of news articles that built analogical bridges from the Holocaust to the violence in Darfur. The introduction offers an especially powerful example from the op-ed pieces of renowned New York Times journalist Nicholas Kristof, who used terms such as Lebensraum and final solution. The numbers presented here show that the likelihood that journalists would cite or make such comparisons was more than one-third higher in American news reports than in those from other countries and more than twice as high in opinion pieces. ${ }^{5}$ Here we see a strong affinity between frames chosen by American movements focused on Darfur and representations in American media. This linkage between civil society movements and media representations is likely to be enhanced by the relative competitiveness of the US media market (Benson 2013). Under such conditions media organizations keep their eyes on and ears attuned to sentiments of those publics they target as customers. Irrespective of such causal issues, however, data show that American civil society and media were major promoters within the international community of criminalizing the violence in Darfur.

\section{UNITED STATES GOVERNMENT}

Given the strength of the Save Darfur movement in the United States, and the substantial support social movements received from media reporting, the US government found itself in a peculiar position within the international community. On the one hand, it had declined to ratify the Rome Statute and in fact fought the creation of the ICC; to this extent, its position to enhance criminal justice intervention against Darfuri actors was weakened. On the other hand, the United States tends to embrace criminalizing frames, domestically and in cases of foreign atrocities, and it was under massive civil society pressure to do so. How did it respond?

Different branches of the US government were certainly receptive to the Darfur-focused movement, which included groups in American society ranging from very conservative to very liberal. The movement was predominantly white, but included passionate involvement of African Americans who identified with those seen as victims of the violence: black Africans. It was thus no surprise when, on June 24, 2004, Representative Donald Payne, Democrat and leading member of the Congressional Black Caucus, joined forces with conservative Republican senator Sam Brownback to introduce a resolution into their respective chambers 
of Congress. Barely a month later, on July 22, 2004, the House and Senate simultaneously passed a resolution declaring that genocide was occurring in Darfur. In the meantime, on June 30, 2004, Secretary of State Colin Powell returned to Washington from Khartoum, declaring the he did not have the information needed to decide whether the violence constituted genocide. Simultaneously, however, he commissioned a survey to be conducted among Darfuri refugees in camps in Chad, just beyond the border of Sudan and Darfur, to gather appropriate information. A basic analysis of this "Atrocities Documentation Survey," with I, I 36 respondents, helped change Powell's position. In a famous hearing before the Senate Foreign Relations Committee, on September 9, 2004, he declared that responses to the survey indicated:

first, a consistent and widespread pattern of atrocities: killings, rapes, burning of villages committed by Jingaweit $[$ sic] and government forces against non-Arab villagers; second, three-fourths of those interviewed reported that the Sudanese military forces were involved in the attacks; third, villages often experienced multiple attacks over a prolonged period before they were destroyed by burning, shelling or bombing, making it impossible for the villagers to return to their villages. This was a coordinated effort, not just random violence. When we reviewed the evidence, ... I concluded that genocide has been committed in Darfur and that the Government of Sudan and the Jingaweit bear responsibility. . . . We believe the evidence corroborates the specific intent of the perpetrators to destroy 'a group in whole and in part,' the words of the [Genocide] Convention. ${ }^{6}$

A few weeks after Secretary Powell's testimony, President Bush himself declared, in a speech to the UN General Assembly, that genocide was part of the pattern of violence in Darfur.

The US government's rhetoric both followed and promoted the American movement that pushed for intervention in Darfur, for labeling the violence genocide, and for criminal prosecution of those responsible. It thus became a player in the field that placed Darfur in the justice cascade. Again, this is remarkable given the US stance regarding the Rome Statute, on which the ICC is based, the very court to which the UNSC referred the Darfur case. The United States allowed the referral to go forward, despite its objections to the ICC, by abstaining from the vote (together with Algeria, Brazil, and China). Actions of the US government were considerably more cautious, however, than its rhetoric. They included, at the UN, sponsorship of the resolution that created the Commission of Inquiry; support, on August 3I, 2006, for a new UN peacekeeping force for Darfur; and-domestically_President Bush's 
signing into law the Sudan Accountability and Divestment Act on December 3I, 2007. This law authorizes local and state governments to divest from Sudan, and excludes companies from federal contracts that operate in Sudan's military, minerals, and oil sectors. ${ }^{7}$

Among the countries I examined, the society-government amalgam in the United States turns out, in cross-national comparison, to have been the strongest force for promoting a crime-focused representation of the Darfur conflict. Specifically, the American narrative privileged the most dramatic depiction of the violence, and its characterization as genocidal, much more than civil societies or governments did in other countries. Three questions arise. Why this forceful amalgam in the case of the United States? Why such as strong movement specifically concerning Darfur? And why did strong representation not translate, in this case, into similarly forceful government action? While I return to country-specific patterns of foreign policy and diplomacy in detail in chapter 7 , a brief paragraph on each of these questions is in order here.

First, reasons for the close correspondence between civil society and government rhetoric lie in the nature of American institutions. The boundary between state and society is particularly porous in the United States (Bendix [1949] 1974; Gorski 2003; Roth 1987; Rueschemeyer I973; Kalberg 20I4; Savelsberg and King 2005). Candidates for legislative office are selected via popular vote in primary elections; the head of the executive branch is elected in a general election; and even many officeholders in the judiciary branch are elected. As a consequence, wherever strong mobilization occurs among civil society groups, especially among constituents of the current administration, the administration and the Congress are likely to be attentive to their demands. And exactly this situation occurred in the case in Darfur. Also the role of media (as a branch of civil society) in the United States is exceptional. Journalism scholarship applies the term media-politics complex to the US, alluding to especially close ties between media and politics; these scholars stress that "the experiences of other countries have been significantly different from the experience of the United States" (Mazzoleni and Schulz I999:258). In addition, news media are driven more strongly by competitive pressures in the US than elsewhere (Benson 20I3). Consequently, they seek alignment with market forces and target groups. A strong civil society movement, encompassing several sectors of society and including a diverse ideological spectrum, is thus likely to leave its traces in media reporting - and especially media commentary-and government actors better listen up or pay a political price. 
Second, the strong American mobilization specifically in the Darfur case is remarkable. Such a response can never be taken for granted when genocide or other mass atrocities occur (Power 2002). In this particular case, however, it resulted from a combination of forces. First among them was the strong representation issuing from specific carrier groups, the crucial contributors to national patterns of knowledge formation to which Max Weber (2009) and Karl Mannheim (1952) alert us in their classic works (see also Kalberg 1994). In the American Darfur mobilization, influential carrier groups included, first, conservative evangelical Christians, a highly mobilized and well-represented constituency for President Bush. Evangelicals had been most active in missionary work in the southern part of Sudan (today South Sudan) when they learned about mass violence in Darfur. When the violence was initially misrepresented as perpetrated by Arabs against Christians, these religious groups spoke up, and the Bush administration listened. Second, once the specter of genocide was raised, Jewish groups became engaged in the cause of Darfur. The USHMM and the AJWS played crucial roles. Further, once victims of the conflict were identified as black, African Americans and the Congressional Black Caucus mobilized. Finally, as public representations now depicted "Arabs" or "Muslims" as perpetrators, it was easy for broad segments of post-September I I American society having anti-Arab or anti-Muslim sentiments to sympathize with the message of the Save Darfur movement. Such mobilization of carrier groups on behalf of Darfur interacted with particular cultural features of US society: a preference for black-and-white depictions of conflicts and an associated punitive orientation toward perpetrators (Whitman 2005), a savior identity in world affairs (Savelsberg and King 20II), and a dominant progressive narrative (Alexander 2004a). Thus, the availability of mobilized, well-organized carrier groups and a conglomerate of cultural features (explored in previous scholarship) help explain the amalgam of forceful state-society representations of mass violence in the case of Darfur as we observed it for the United States.

Third, there were multiple reasons why the US government, despite intense American rhetoric, did not more aggressively pursue the case of Darfur in its actions. These factors include, first, the growing skepticism toward military engagement abroad that began to grow among the American public after the costly and much debated interventions in Afghanistan and especially Iraq. Government actors were also concerned with the country's increasingly thin-stretched military capacities. In addition, the US government sought cooperation from the Sudanese government in its 
fight against al Qaida terrorism. To secure such cooperation, it was even willing to temporarily downgrade its rhetoric and lower its estimates of the death toll in Darfur as Hagan and Rymond-Richmond (2008) show. The American administration had also been a strong force in the Comprehensive Peace Agreement between North and South Sudan, and many diplomats likely saw cooperation on the part of the al-Bashir regime as a necessary condition for its implementation. Finally, social movements can at times be easily pacified by symbolic government actions, such as those the US administration and Congress delivered.

\section{EXCURSUS: AMNESTY AND SAVE DARFUR-STRATEGIES OF GLOBAL ACTORS IN NATIONAL CONTEXTS}

Within the massive Save Darfur movement, Amnesty-USA had to find its place without disconnecting from the principles of the international organization, its many other national sections, and its headquarters in London. My interview with an American Amnesty activist, volunteer, and coordinator of the US Darfur campaign, revealed organizational and linguistic strategies that helped the national section navigate between its international obligations and its domestic environment:

Amnesty International wanted a Darfur coordinator. . . . I volunteered to do this, but I recognized that there was a lot more with this than report to the group what Amnesty was doing and have them sign letters. I saw what the interests were of the group members. Somebody was very interested in violence against women, so I connected that [Darfur] to violence against women in armed conflict. . . . I created a yearlong panel series on violence against women in armed conflicts. ... And it was very successful. I got funding from Amnesty. This was all as a volunteer.

In addition to strategies to broaden the campaign and bring it in line with diverse strains of American civil society engagement, Amnesty activists had to manage divergences between Save Darfur and AmnestyUSA strategies. One example is Save Darfur's demands for divestment, a method Amnesty did not support. One interviewee described organizational strategies to circumvent such conflict: "I saw an opportunity to marry two strains of activism, to keep Amnesty current and to bring people into the fold that wanted to work with Amnesty but couldn't because they supported divestment and Amnesty didn't. So I created an economic activism campaign, centered on the oil industry. So that way, people who wanted to do Amnesty, and who were interested in divestment . . could do stock- and stakeholder engagement. It gave them a way to try to impact the oil industry." 
Such organizational inventiveness, a skilled effort to maneuver between American activism and international, centralized Amnesty, is supplemented by linguistic strategies. Again, a conflict had to be resolved, in this case conflict over language. The Save Darfur movement insisted on calling the violence in Darfur genocide, a position Amnesty rejected. In the words of the volunteer interviewee: "I had to work with a lot of people who thought we should . . . call it a genocide. I spoke to a lot of groups, gave a lot of talks. And I would always say, whether you call it genocide or crimes against humanity, we know there were mass atrocities, and that the government is targeting its own civilians. And whatever we want to call it, the response is the same."

Working in the context of the larger US movement, Amnesty activists thus became organizationally and linguistically innovative. This allowed them to operate effectively in the United States-another illustration of the fact that national conditions matter even within INGOs, and an observation in support of Stroup's (2012) findings about the weight of national contexts in INGO work. ${ }^{8}$ But these adaptive strategies also show that contradictions between international and national positions can be managed. It also matters, of course, that AmnestyUSA is Amnesty's largest national section. Activists are aware of the fact that Amnesty-USA's size provides them with strength within the larger organization despite the formal leadership of the International Secretariat. "Well, the US section is the largest," one respondent said. "I was in Amsterdam for a meeting of different sections that were working on Sudan. And I was learning that European sections were coming to the US website and using our materials. . . . The reason I bring this up is that the US section was driving more of the Darfur campaign. We wanted more. We wanted to be doing more. We wanted to push the envelope. [JJS: “More than the International Secretariat?"] Yeah. Yeah.” This comment is significant as it illustrates how activists within a national section do not just have to engage in organizational and linguistic maneuvers between contending forces in their home country, vis-à-vis the discipline demanded by their international headquarters. To bridge the gap, they may actually seek to pull the INGO over to their national campaign strategy, at least when representing a powerful country such as the United States. And yet the effect of such strategies is limited. National sections continue to be bound by the organization's agenda as defined, in the case of Amnesty, by the International Secretariat.

Interested in the effects this tug-of-war between national movements and INGOs has on the representation of Darfur, I worked with two students at the University of Minnesota, Meghan Zacher and Hollie Nyseth 
Brehm, to analyze the websites of Save Darfur and Amnesty-USA. ${ }^{9}$ Methodological and substantive details of this study are reported elsewhere (Zacher, Nyseth Brehm, and Savelsberg 20I4; see also note 4); ${ }^{\text {IO }}$ a summary of findings suffices here. Our analysis of websites shows that representations of the Darfur conflict, as part of a broad-based American civil society campaign, did differ between Amnesty-USA and Save Darfur. Amnesty's website engaged in a more detailed depiction of different types of victimization. The pages displayed rapes much more frequently than Save Darfur and, somewhat more often, killings and the destruction of livelihood through looting, burning villages and crops, and poisoning water sources. Amnesty webpages also referred more often to categories of international criminal law, depicting the violence as a violation of international humanitarian law and human rights. Save Darfur web entries, on the other hand, used simpler and more dramatic vocabulary. Instead of specifying types of crimes, they more often simply referred to what had occurred as "criminal violence" (85\% compared to Amnesty's 3I\%). Most important, while AmnestyUSA web entries almost completely avoid reference to genocide, in line with the international organization's policy, Save Darfur sites-in line with the central message of the campaign-insist on calling the violence just that: genocide (more than $70 \%$ of all Save Darfur entries).

In one respect, however, Amnesty-USA (in line with the International Secretariat's policy) and Save Darfur agree. Both urge interventions by the ICC. Even if such support is explicated somewhat more frequently on Save Darfur sites $(35 \%)$, it certainly appears prominently on Amnesty-USA sites as well (25\%). On February I, 2005 , after the delivery of the Commission of Inquiry report to the UN Security Council, executive director of Amnesty-USA Dr. William F. Schulz was quoted as saying: "Given the scale and sheer horror of the human rights abuses in Darfur, anything less than immediate action on the report's findings would be a travesty for the people of Darfur. The International Criminal Court should be given jurisdiction to prosecute war crimes and crimes against humanity that have taken place in Sudan." ${ }^{\text {II }}$ In the United States such a demand is backed by Save Darfur, the movement within which Amnesty-USA was one among almost two hundred constituent organizations. For instance, in an article written on April 27, 2007, the day on which an arrest warrant was issued against Ahmed Harun and Ali Kushayb, two leading perpetrators in Darfur, Save Darfur's executive director stated, "We welcome the ICC's continued efforts to ensure accountability for the genocide in Darfur. This important step by the court sends yet another message to the government 


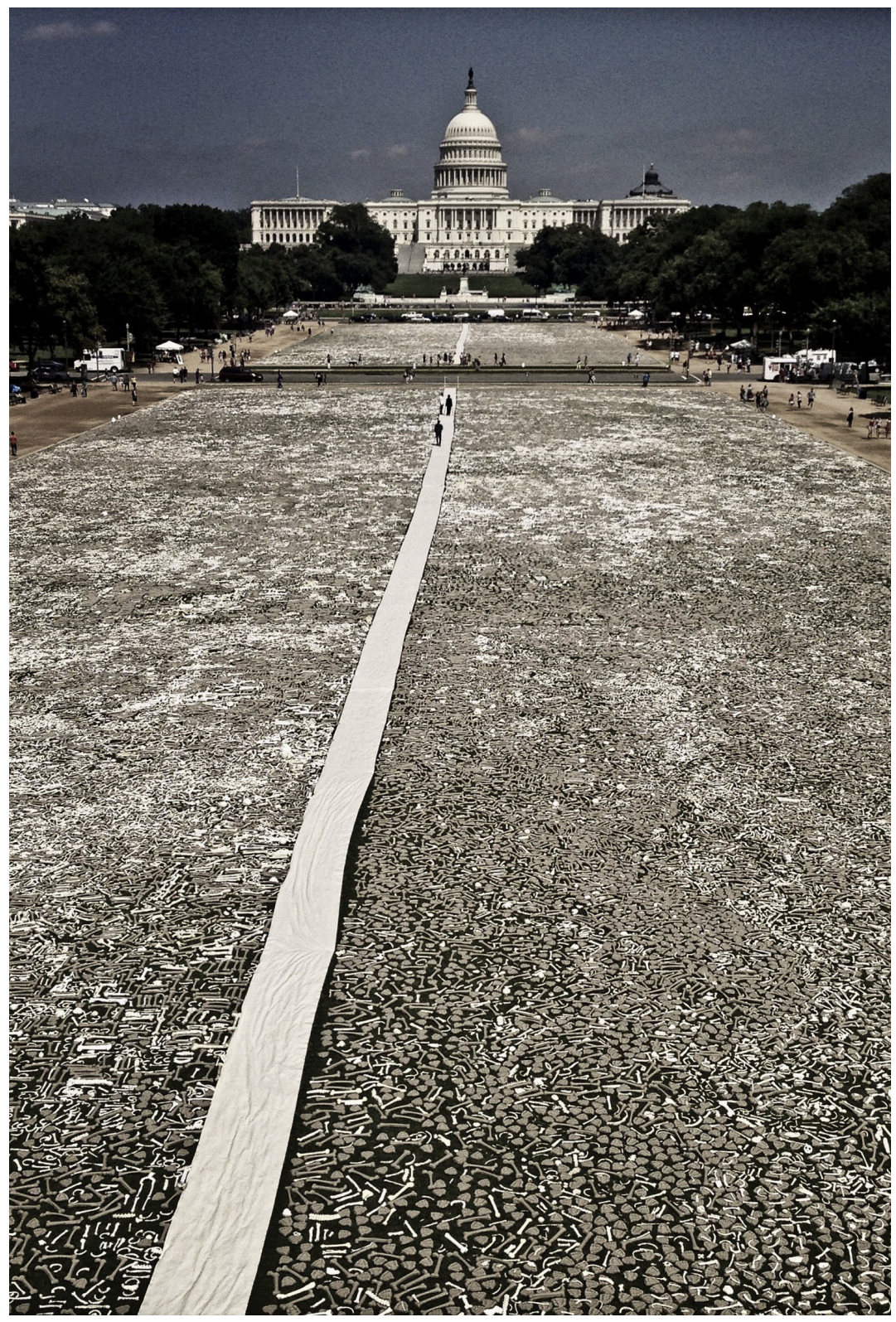

FIGURE IO. Naomi Natale's artistic rendering of genocidal violence, mounted by the One Million Bones project in Washington, DC, June 2013. This photo appeared on Save Darfur's website. 
of Sudan that the international community will bring to justice those responsible for these horrendous crimes." ${ }_{\text {I2 }}$ Clear statements were accompanied by massive demonstrations and demands for justice. They also spurred artistic depictions, which appeared on the websites of movement organizations (see figure Io).

In short, while interview statements illustrate how activists of national sections of INGOs (here Amnesty-USA) seek to build organizational and linguistic bridges to domestic political movements (Save Darfur in our case), public representations of massive violence as displayed on websites of the national section remain distinct from national contexts and in line with the INGO's central policies. With regard to the perceived necessity of ICC interventions, however, both organizations agree: they strongly advocate criminal justice intervention by the International Criminal Court against those responsible for the mass violence in Darfur. In their general assessment of the situation-as a campaign of criminal, indeed genocidal, violence or as war crimes and crimes against humanity respectively—and in the conclusions drawn for judicial intervention, NGOs in the United States aligned closely with other segments of American civil society, as our media analysis documented. And they shaped the rhetoric of the US government.

\section{CONCLUSIONS REGARDING THE PERIPHERY OF THE JUSTICE FIELD}

Clearly, in the United States, civil society and government stood out in international comparison as both sought to advance a criminalizing frame for Darfur and a definition of the violence as genocide. This does not mean, as we have seen, that rhetoric necessarily translates into action. Obviously the Clinton administration was mistaken when it refused to identify the 1994 violence in Rwanda as genocide, fearing that such a label would necessarily prompt military intervention. The George W. Bush administration proved this assumption wrong in the case of Darfur. It spoke loudly about genocide but refused to intervene decisively. Further, despite the rather forceful mobilization and rhetoric in the Darfur case, the world cannot always rely on the United States and American civil society when mass atrocities are being committed. As discussed above, the American response to Darfur was characterized by a particular constellation of societal and cultural conditions. It contrasts with the silence shown in many other cases, such as the long-lasting lack of public and governmental attention to the long and 
painful history of the Democratic Republic of Congo with its fractured lines of conflict. More extreme are cases, such as those in Guatemala, in which American civil society long failed to react to massive human rights violations and genocidal violence abroad despite the US government's own contributions to their execution.

Despite noting gaps between rhetoric and practice, and even instances of massive cynicism, this chapter shares one essential finding with the preceding ones. It shows how the entire justice field, both core and periphery, including international judicial institutions, rights-oriented INGOs, civil society movements, and supportive governments, contributes to a representation of the mass violence of Darfur that deviates radically from those of comparable situations in past centuries and millennia. The emerging narrative depicts those responsible for mass violence as criminal perpetrators and their actions as crimes. This narrative has moved us far from eras in which leaders of violent campaigns were celebrated as heroes (Giesen $2004 \mathrm{~b}$ ). In addition, this new narrative and its construction across national boundaries opens the eyes of the public to the suffering of victims. It supports Jenness's (2004:I60) contention that criminalization processes in late modernity reflect an "institutionalization that involves the diffusion of social forms and practices across polities comprising an interstate system." In Darfur and in other cases like it, global actors, here especially the UNSC and the ICC, play a central role in this diffusion process.

Finally, the justice narrative has at least the potential of ingraining in the global collective conscience the notion of mass violence as evil, through a process described in recent work on collective memory (Bass 2000; Osiel I997; Levy and Sznaider 2010) and its classical predecessors (Durkheim [I9I2] 200I; Halbwachs I992). That representations of mass violence adapt to national context may be considered a disadvantage by some; others may regard it as advantageous, as global movements always concretize in local contexts, succeeding only if they adjust to local conditions. The story of Amnesty International in the US context is a case in point. An earlier word of caution bears repeating, though. By creating criminalizing narratives, the justice field buys into the limits imposed by the institutional logic of the criminal law. The resulting account, neglecting structural conditions and historical roots, may be too limited a foundation for long-term policies that can prevent mass violence and genocide. Then again, the criminal justice field is not the only representational force. Its narrative faces other, conflicting ones, narratives to which I now turn. 